\title{
EFEKTIVITAS DISKON DAN HADIAH SEBAGAI SARANA PROMOSI PENJUALAN UNTUK MENARIK NIAT BELI KONSUMEN PADA BUMBU MAGIC LEZAT
}

\author{
Amir Faesol \\ PT. Gawih Jaya - Wismilak \\ E-mail:amir_faesol@ymail.com
}

\begin{abstract}
This research aimed to analyse (1) the consumer attitudes to discounts and gifts,(2) whether consumer attitudes to discounts and gifts have effectiveness in influencing purchase intention, (3) whether purchase intentions influence on purchase decisions, (4) differences in attitudes effectiveness of direct influence attitudes towards buying decision (5) the direct influence of attitudes on purchase decisions through intention. The samples were 152 respondents and selected by using purposive sampling technique. The data was collected by distributing questionnaires to consumers Lezat Magic seasoning. The primary data were consists of discount gift attitudes, purchase intentions and purchase decisions. Partial Least Square was used as an analysis tool to answer the research objectives. The results showed that consumers preferred to have promotional gifts and they compared it with discounts. The discounts and gifts significantly influenced to purchase intention. Furthermore, purchase intentions significantly influenced to purchase decisions. Moreover, it showed that the more effective influence of attitudes to discounts and gifts to purchase decision through intention than without intention. It meant there was differences influential between attitude to discount and gifts to buying decision with and without intention.
\end{abstract}

Keywords: Attitudes to discounts and gifts, purchase intention and the purchase decision

\section{PENDAHULUAN}

Semakin tumbuh dan berkembangnya ilmu dan teknologi, berdampak terhadap berkembangnya perekonomian dan selanjutnya diikuti oleh sejumlah pelaku bisnis. Hal ini menciptakan persaingan yang semakin ketat dan kompetitif dalam dunia usaha, sehingga memerlukan berbagai cara dan strategi untuk menghadapinya. Salah satu strategi yang digunakan perusahaan yaitu dengan menggunakan dan memaksimalkan promosi penjualan, dalam meningkatkan penjualan dan meningkatkan minat beli konsumen terhadap produk yang telah diberi program promosi penjualan.

Promosi penjualan adalah perangkat komunikasi yang semakin banyak digunakan oleh perusahaan karena kemampuannya dalam menghasil- kan penjualan yang tinggi(Montaner \& Pina, 2008). Tujuan dari adanya promosi penjualan adalah mengarahkan konsumen untuk melakukan pembelian produk baru serta sebagai informasi dalam konsumen memilih produk (Haresh, 2011). Salah satu bentuk promosi penjualan yaitu discount atau potongan harga dan hadiah langsung. Promosi dalam bentuk potongan harga (discount) secara konsisten menimbulkan peningkatan minat beli konsumen (Lexchin \& Mintzes, 2002). Raghubir (2008) melakukan penelitian tentang pengujian pengaruh terhadap ukuran viasual dari hadiah gratis pada penilaian konsumen. Hasil penelitiannya yaitu penawaran promosi dengan hadiah gratis (bukan produk) kurang efektif dan akan mengurangi daya tawar produk kepada konsumen sehingga akan mempengaruhi niat pembelian konsumen. 
Penelitian sebelumnya belummenjelaskan secara detail mengenai bentuk promosi penjualan yaitu discount dan hadiah secara efektif bisa menimbulkan dan meningkatkan pembelian suatu produk. Promosi yang efektif dapat meningkatkan volume penjualan dan pembelian produk. Begitu juga halnya persaingan pada perusahaan bumbu Magic Lezaat yang memiliki pesaing yang kuat seperti Royco, Masako, Sasa dan lain sebagainya. Penelitian ini dilakukan di Pasar Besar Malang. Berdasarkan uraian di atas dapat ditarik rumusan masalah sebagai berikut bagaimana sikap konsumen terhadap diskon dan hadiah?, apakah sikap konsumen terhadap diskon dan hadiah memiliki efektifitas dalam mempengaruhi niat beli?, apakah niat pembelian berpengaruh terhadap keputusan pembelian?, apakah sikap terhadap diskon dan hadiah berpengaruh terhadap keputusan pembelian?

\section{TINJAUAN PUSTAKA}

Kajian mengenai efektifitas promosi penjualan telah banyak dilakukan oleh peneliti sebelumnya. Seperti, Rockney (1988) menguji mengenai dampak dari promosi harga terhadap kinerja toko, dari hasil penelitiannya diperoleh bahwa dampak dari promosi tersebut bervariasi tergantung pada kinerja yang diperiksa, dan promosi harga ini sangat membantu kinerja toko dalam menjual suatu barang atau perputaran produk di dalam sebuah toko (turn over produk). Sementara Lemchi et al., (2008), melakukan penelitian dengan tujuan untuk mengevaluasi pengaruh promosi penjualan pada volume penjualan bumbu masak Royco di Onitsha. Hasil dari temuan menunjukkan adanya hubungan yang positif antara promosi penjualan dengan volume penjualan pada bumbu Royco. Artinya promosi penjualan memiliki kontribusi terhadap besarnya volume penjualan.
Penelitian ini memiliki kesamaan dengan penelitian yang pernah dilakukan oleh Raghubir (2008) melakukan penelitian tentang pengujian pengaruh terhadap ukuran viasual dari hadiah gratis pada penilaian konsumen. Hasil penelitiannya yaitu penawaran promosi dengan hadiah gratis (bukan produk) kurang efektif dan akan mengurangi daya tawar produk kepada konsumen sehingga akan mempengaruhi niat pembelian konsumen. Sementara Raghubir (2004) dalam risetnya mengenai persepsi konsumen terhadap hadiah gratis dan diskon harga serta dampak terhadap penilaian pada produk tersebut. Hasil dari penelitiannya pemberian nilai diskon dan hadiah gratis akan meniumbulkan persepsi konsumen tentang nilai hadiah dan produk itu sendiri.

Dalam The Thoery of Planned Behavior Keyakinan perilaku, keyakinanan normatif dan kontrol keyakinan saling berpengaruh dalam membentuk sikap, norma subjektif dan persepsi terhadap perilaku pengendalian dan seterusnya akan membentuk suatu niat. Perilaku dibentuk dari suatu niat yang dipengaruhi pula oleh pengendalian aktual kontrol. Kontrol perilaku yang dirasakan (Perceived Behaviourals Control) merupakan kondisi dimana seseorang percaya bahwa suatu tindakan dapat dirasakan mudah atau sulit untuk dilakukan. Secara lebih detail dapat digambarkan The Thoery of Planned Behavior seperti yang tersaji pada Gambar 1 berikut:

Promosi yang efektif dapat meningkatkan volume penjualan dan pembelian produk. Pada dasarnya pengertian efektivitas yang umum menunjukkan pada taraftercapainya hasil. Promosi juga dapat menimbulkan suatu peluang akan kebutuhan konsumen untuk dapat mengingat kembali, sehingga dapat menciptakan peluang untuk melakukan transaksi pembelian (Nira \& Idson, 1999). Promosi penjualan merupakan salah alat

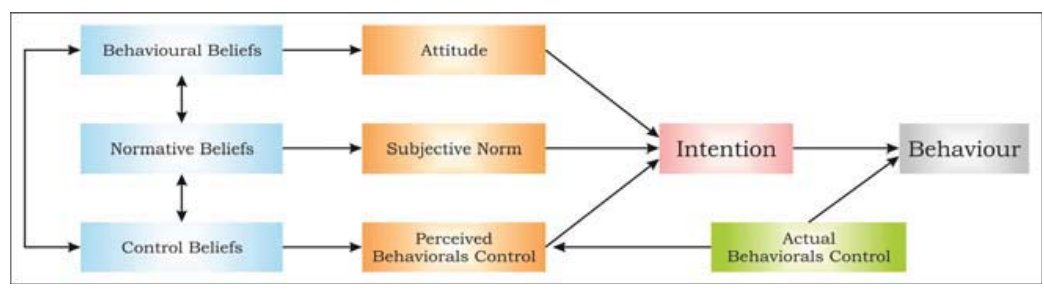

Gambar 1: The Thoery of Planned Behavior (Sumber: Ajzen, 2006) 
pemasaran pada perusahaan ritel. Dalam promosi penjualan yang digunakan oleh perusahaan yaitu promosi untuk toko atau penjual (Trade Promotion) dan promosi untuk pembeli (Consumer Promotion). Kraft et al., (2006).

Discount pada toko ritel akan membentuk sikap konsumen, kemudian kepuasan konsumen serta loyalitas konsumen, yang pada akhirnya akan menguntungkan dari toko ritel tersebut (Doong, 2003). Discount akan menjadi sumber informasi yang digunakan konsumen dalam membuat penilaian tentang produk dan harga (Raghubir, 2004). Hadiah merupakan salah satu alat promosi yang dapat menarik minat konsumen untuk melakukan pembelian (Ayantunji, 2007). Sementara Raman $\&$ Prasad (2011) hadiah dipandang sebagai penarik minat konsumen untuk bisa melihat (harga, kemasan, warna dan flavour). Dampak dari promosi penjualan yang berbentuk hadiah yaitu Program hadiah memiliki pengaruh positif terhadap peningkatan pembelian konsumen pada toko ritel (Ayala et al., 2004).

Allen et al., (dalam Azwar, 1995), mendefinisikan sikap sebagai pola perilaku, tendensi atau kesiapan antisipatif, predis posisi untuk menyesuaikan diri dalam situasi sosial, sikap adalah respon terhadap stimulus sosial yang telah terkondisikan. Widayat (2011) mengemukakan bahwa sebagai suatu respon evalutif sikap akan muncul bila dihadapkan pada objek sikap. Respon akan timbul bilamana seseorang dihadapkan pada suatu stimulus yang menghendaki timbulnya reaksi.
Menurut Theory of Planned Behaviour (TPB), perilaku membeli ditentukan oleh niat pembelian, dimana hal tersebut ditentukan oleh sikap (Fishbein and Ajzen, 1975). Dengan mengacu pada Theory of Planned Behaviour (TPB), niat konsumen dalam melakukan pembelian akan semakin besar jika sikap dan norma subjektif semakin baik dan kontrol keperilakuan juga semakin besar pula. Niat merupakan sebagai salah satu variabel penentu terhadap perilaku yang sebenarnya. Perilaku konsumen merupakan studi tentang cara individu, kelompok dan organisasi dalam menyeleksi, membeli, menggunakan barang dan jasa. Secara lebih ringkas Kotler \& Keller (2009) mengambarkan model perilaku konsumen seperti pada Gambar 2 berikut:

Dari gambar 2 dapat dijelaskan bahwa pemasaran dan rangsangan lingkungan memasuki kesadaran konsumen. Satu perangkat proses psikologi berkombinasi dengan karakteristik konsumen tertentu untuk menghasilkan proses keputusan dan keputusan pembelian. Tugas pemasar adalah memahami apa yang terjadi dalam kesadaran konsumen antara datangnya rangsangan pemasaran luar dan keputusan pembelian akhir. Empat proses psikologi (motivasi, persepsi, pembelajaran dan memori) secara fundamental mempengaruhi tangapan konsumen terhadap berbagai rangsangan pemasaran. Bentuk dari komunikator pada rangsangan pemasar yaitu promosi. Bauran promosi terdiri dari lima macam yaitu, periklanan, promosi penjualan, hubungan masyarakat, penjual-

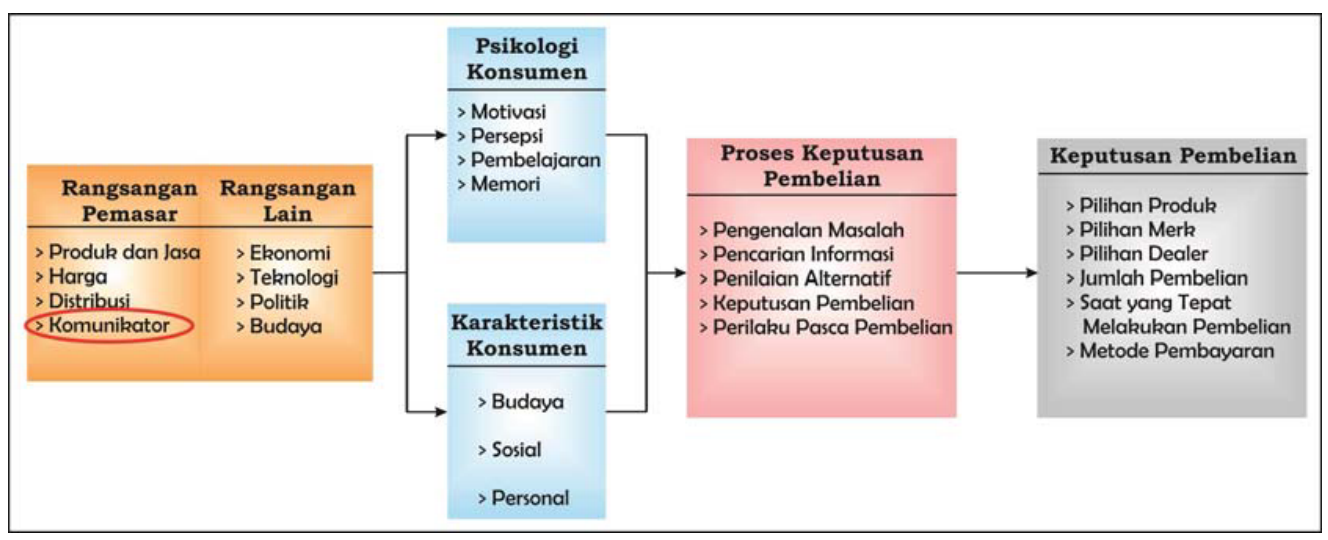

Gambar 2: Model Perilaku Konsumen

(Sumber: Kotler \& Keller, 2009) 
an pribadi, dan pemasaran langsung. Discount dan hadiah merupakan bagian dari alat promosi penjualan.

Mengacu pada kajian teori yang telah dikemukakan di atas dapat dirancang suatu kerangka berpikir bahwa konsumen akan menyikapi suatu rangsangan promosi penjualan, khususnya discount dan hadiah pada suatu produk yang akan mempengaruhi suatu niat untuk melakukan suatu evaluasi sebelum memutuskan keputusan pembelian. Keputusan pembelian merupakan variabel yang dipengaruhi oleh berbagai variabel. Variabel tersebut diantaranya variabel sikap dan variabel niat beli. Penelitian ini dapat dihipotesiskan sebagai berikut:

H1: Sikap konsumen terhadap diskon dan hadiah memiliki efektifitas dalam mempengaruhi niat beli

$\mathrm{H} 2$ : Niat memiliki pengaruh yang positif dan signifikan terhadap keputusan pembelian

H3: Sikap memilikipengaruh positif dan signifikan terhadap keputusan pembelian

Sementara kerangka pikir pada penelitian ini seperti yang tersaji pada gambar 3 berikut:

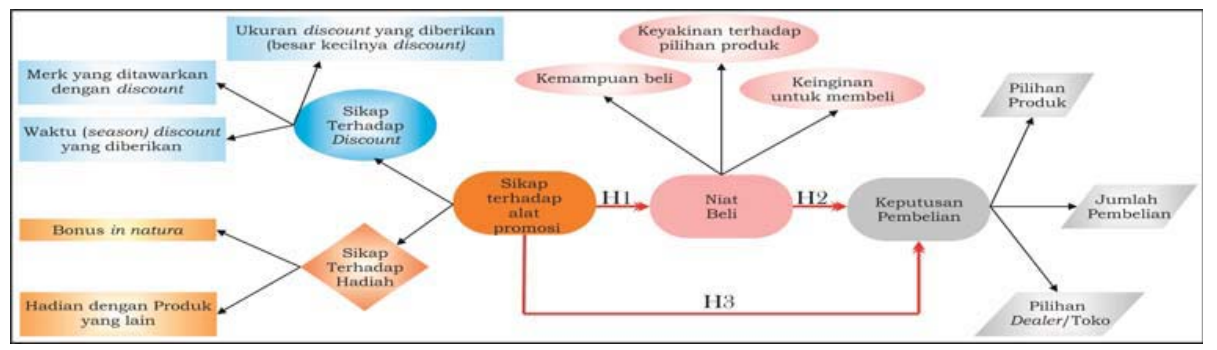

Gambar 3: Kerangka Berpikir

\section{METODE PENELITIAN}

Dalam penelitian ini populasinya adalah keseluruhan konsumen Bumbu Magic Lezat pada Pasar Besar Malang. Peneliti dalam mengambil populasi yaitu dengan mengunakan konsumen yang melakukan pembelian di outlet yang terdaftar pada Indomarco yaitu selaku distributor Bumbu Magic
Lezat pada pasar Besar Malang. Jumlah populasi dalam penelitian ini tidak diketahui secara pasti atau bersifat infinity. Outlet atau toko yang terdaftar sebagai outlet langganan Indomarco yaitu sejumlah 175 outlet, dengan kriteria 23 toko merupakan toko grosir dan 152 merupakan toko retail. Seperti yang tersaji pada gambar 4 berikut:

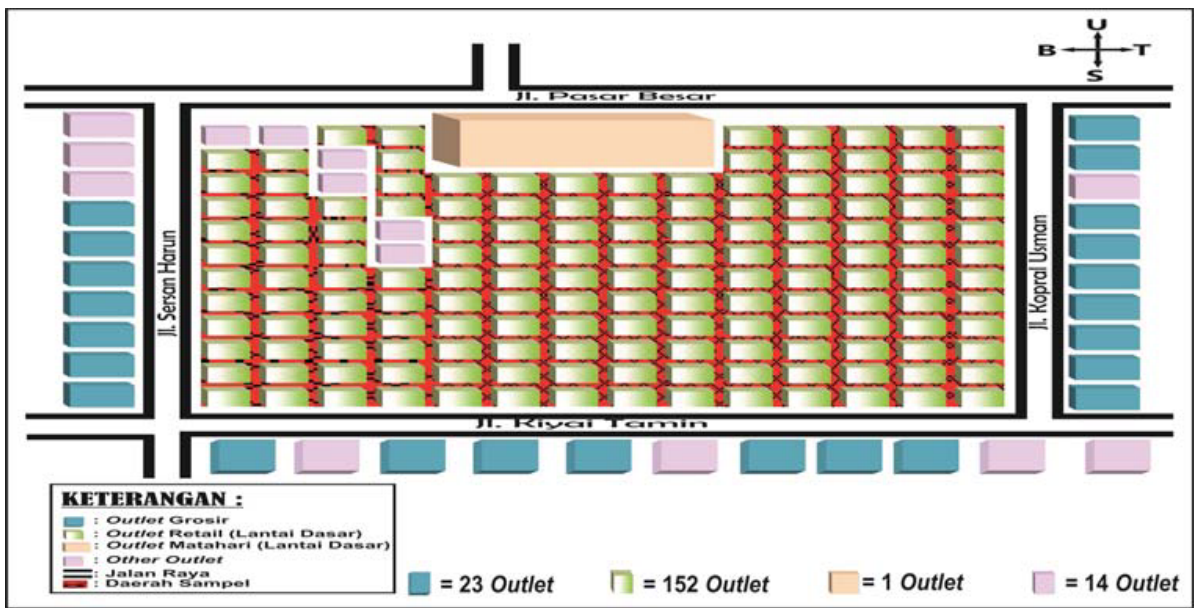

Gambar 4: Ilustrasi Denah Pasar Besar 
Dari Gambar 4 dapat dijelaskan bahwa populasi merupakan keseluruhan toko retail berada di kawasan di dalam pasar dan daerah tersebut merupakan daerah sampel (gambar yang diarsir). Daerah sampel merupakan pelanggan dari toko retail, dimana tipe pelanggan toko retail tersebut adalah pengguna langsung atau pengguna terakhir (end user) dari bumbu Magic Lezaat. Penyebaran kuesioner dilakukan selama empat hari tepatnya dari tanggal empat sampai dengan tujuh Feburari 2013. Untuk menguji instrumen penelitian, maka dilakukan uji validitas dan reabilitas. Dikatakan valid, jika instrumen memiliki nilai outer loading lebih besar dari 0,5. Sementara instrumen dinyatakan reliabel jika memiliki nilai consistensy dan cronbach's Alpha lebih besar dari 0,6 (Wiyono, 2011). Suatu instrumen dikatakan reliabel, jika memiliki nilai cronbach's Alpha atau internal consistensy lebih besar dali 0,6. Nilai internal consistency dan cronbachs alpha tersaji pada tabel 1 berikut:

Tabel 1: Nilai internal consistency dan cronbachs alpha

\begin{tabular}{lccc}
\hline \multicolumn{1}{c}{ Variabel } & Composite Reliability & Cronbachs Alpha & Keterangan \\
\hline Diskon & 0,930095 & 0,889374 & Reliabel \\
Hadiah & 0,635591 & 0,807404 & Reliabel \\
Niat & 0,870608 & 0,821077 & Reliabel \\
\multirow{2}{*}{ Keputusan Pembelian } & 0,830663 & 0,709570 & Reliabel \\
\hline
\end{tabular}

Sumber: Print Out PLS

Alat analisa yang digunakan dalam penelitian mengunakan Partial Least Square (PLS). Sedangkan uji hipotesis dilakukan dengan menggunakan uji t. Uji t dilakukan dengan cara membandingkan nilai t- statistik dengan t- tabel. Hipotesis diterima jika nilai t-statistik $>$ t-tabel.

\section{HASIL PENELITIAN DAN PEMBAHASAN}

Sikap konsumen terhadap diskon dapat dijelaskan melalui jawaban pada masing-masing item pertanyaan kemudian diolah pada data statistik deskriptif. Dari hasil olah data statistik deskriptif diketahui bahwa rata-rata jawaban responden pada item pertanyaan sikap konsumen terhadap diskon adalah netral yang ditunjukkan oleh angka mean sebesar 3,84. Hal ini mengindikasikan bahwa sikap konsumen berada pada kutub netral atau tidak memihak dalam menilai diskon yang ada pada Bumbu Magic Lezaat. Sementara untuk sikap terhadap hadiah dapat digambarkan bahwa rata - rata jawaban responden pada dua item pertanyaan sikap konsumen terhadap hadaih pada bumbu Magic
Lezaat adalah suka dan pantas yang ditunuukan dengan nilai maen sebesar 4. Angka ini menunjukkan indikasi suka dan pantas atas hadiah sendok. Dengan demikian konsumen lebih memilih hadiah daripada diskon. Inner Model menggambarkan hubungan antar variabel laten (Wiyono, 2011). Pengujian Inner Model dilakukan dengan melihat besarnya nilai dari R-square variabel endogen dan koefisien parameter jalur strukturalnya yang dapat dilihat melalui prosedur bootstrapping.

Penilaian model penelitian dimulai dengan melihat nilai R-square untuk setiap variabel endogen. Perubahan nilai R-square dapat digunakan untuk menilai besarnya kontribusi variabel laten eksogen tertentu terhadap variabel laten endogen. Nilai R-square dalam penelitian ini dapat dilihat pada tabel 2 berikut:

Tabel 2: Nilai R- square pada setiap variabel penelitian

\begin{tabular}{lc}
\hline \multicolumn{1}{c}{ Variabel } & R- square \\
\hline Niat & 0,735079 \\
Keputusan Pembelian & 0,981339 \\
\hline
\end{tabular}


Nilai R-square pada variabel niat sebesar 0,735079. nilai ini mampu menunjukkan bahwa variabel niat dijelaskan oleh variabel sikap terhadap diskon dan sikap terhadap hadiah sebesar $74 \%$. sedangkan $26 \%$ dijelaskan oleh variabel lain yang tidak disertakan dalam penelitian ini. Nilai Rsquare pada variabel keputusan pembelian sebesar 0,981339 , nilai ini mampu menunjukkan bahwa variabel keputusan pembelian dijelaskan oleh variabel sikap terhadap diskon sikap terhadap hadiah dan niat sebesar 98\%. sedangkan 2\% dijelaskan oleh variabel lain yang tidak disertakan dalam penelitian ini. Koefisien parameter digunakan untuk menentukan arah hubungan antara variabel laten independen dengan laten dependennya. Secara lengkap nilai koefisien parameter dapat dilihat pada tabel 3 berikut:

Tabel 3: Nilai Path Koefisien setiap jalur Hubungan Variabel Penelitian

\begin{tabular}{lc}
\hline \multicolumn{1}{c}{ Jalur Hubungan } & Path Koefisien \\
\hline Sikap terhadap niat & 0,857367 \\
Sikap terhadap keputusan pembelian & 0,232106 \\
Niat terhadap keputusan pembelian & 0,784395 \\
\hline
\end{tabular}

Tabel 3 dengan jelas menunjukkan bahwa semua koefisien parameter hubungan antara variabel eksogen terhadap variabel endogen adalah bernilai positif. Nilai positif tersebut mengindikasikan bahwa variabel laten eksogen berpengaruh secara positif terhadap variabel laten endogen. Koefisien parameter yang tertinggi adalah koefisien hubungan antara sikap terhadap hadiah dengan nilai 0,919651 .

Sementara nilai koefisien terendah ada pada hubungan antara variabel sikap terhadap keputusan pembelian yaitu sebesar 0,232106 . Artinya sikap yang terbentuk atas suatu objek tidak bisa menggambarkan tindakan keputusan pembelian akan terjadi. Hal ini mengindikasikan bahwa suatu keputusan pembelian akan terlaksana tidak cukup dengan adanya suatu sikap belaka, melainkan ada variabel lain atau faktor yang akan memperkuat terjadinya suatu perilaku pengambilan keputusan. Koefisien yang ada dalam penelitian ini bisa dilihat pada Gambar 5 berikut:

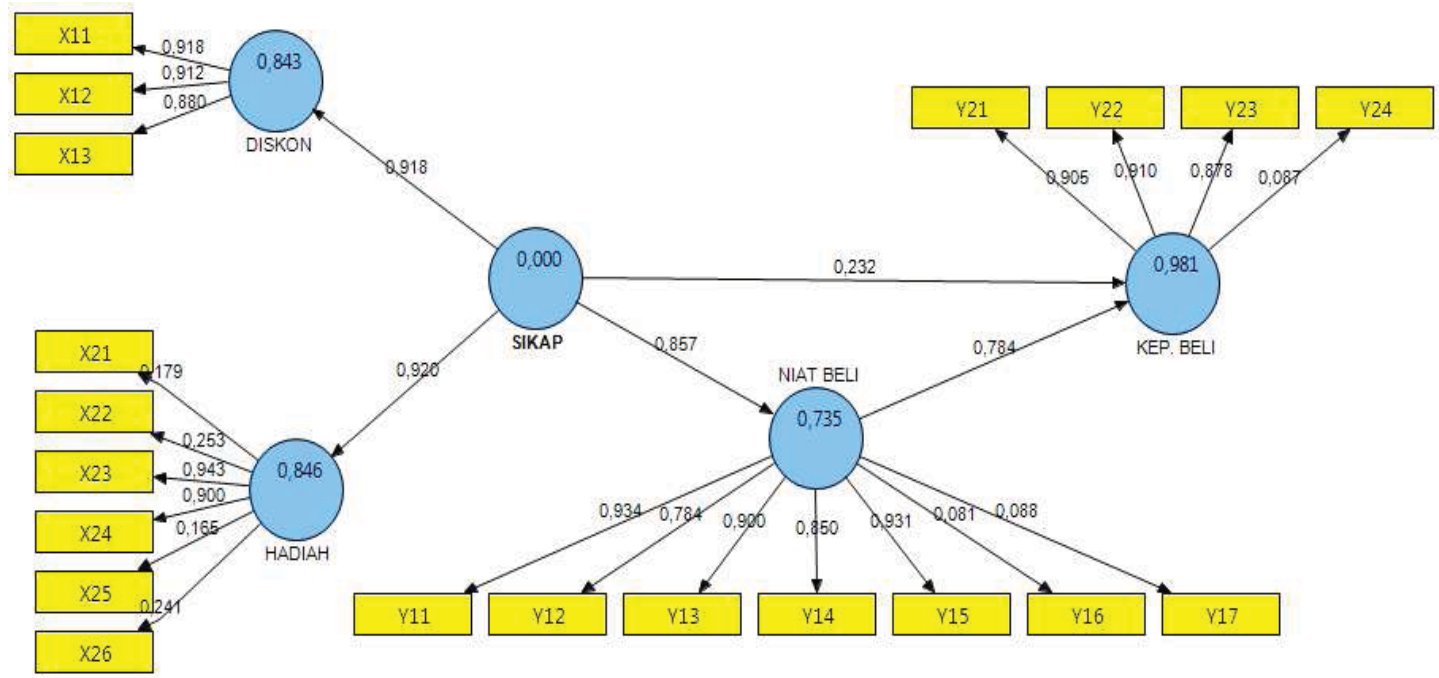

Gambar 5: Model hubugan antar variabel penelitian 
50 Jurnal Manajemen Bisnis • Volume 3 No. 01 • Edisi April 2013

Pengujian hipotesis yang diajukan diuji dengan membandingkan nilai t-statstik yang diperoleh dari inner weight pada pengolahan PLS dan t-tabel tersaji pada tabel 4 berikut:

Tabel 4: Pengujian Hipotesis Penelitian

\begin{tabular}{llccc}
\hline & \multicolumn{1}{c}{ Hipotesis } & t statstik & t-tabel & Keterangan \\
\hline H1: & $\begin{array}{l}\text { Sikap konsumen terhadap diskon dan hadiah } \\
\text { memiliki efektifitas dalam mempengaruhi niat }\end{array}$ & 27,491 & 1,655 & Diterima \\
beli & & 16,712 & 1,655 & Diterima \\
H2: $\quad \begin{array}{l}\text { Niat berpengaruh positif terhadap keputusan } \\
\text { pembelian }\end{array}$ & 4,491 & 1,655 & Diterima \\
$\begin{array}{l}\text { Sikap berpengaruh positif terhadap keputusan } \\
\text { pembelian }\end{array}$ & & & \\
\hline
\end{tabular}

Sementara untuk hasil nilai t-statistik pada pengaruh antar variabel diperoleh dari out put perhitungan Boostraping nampak pada Gambar 6 berikut:

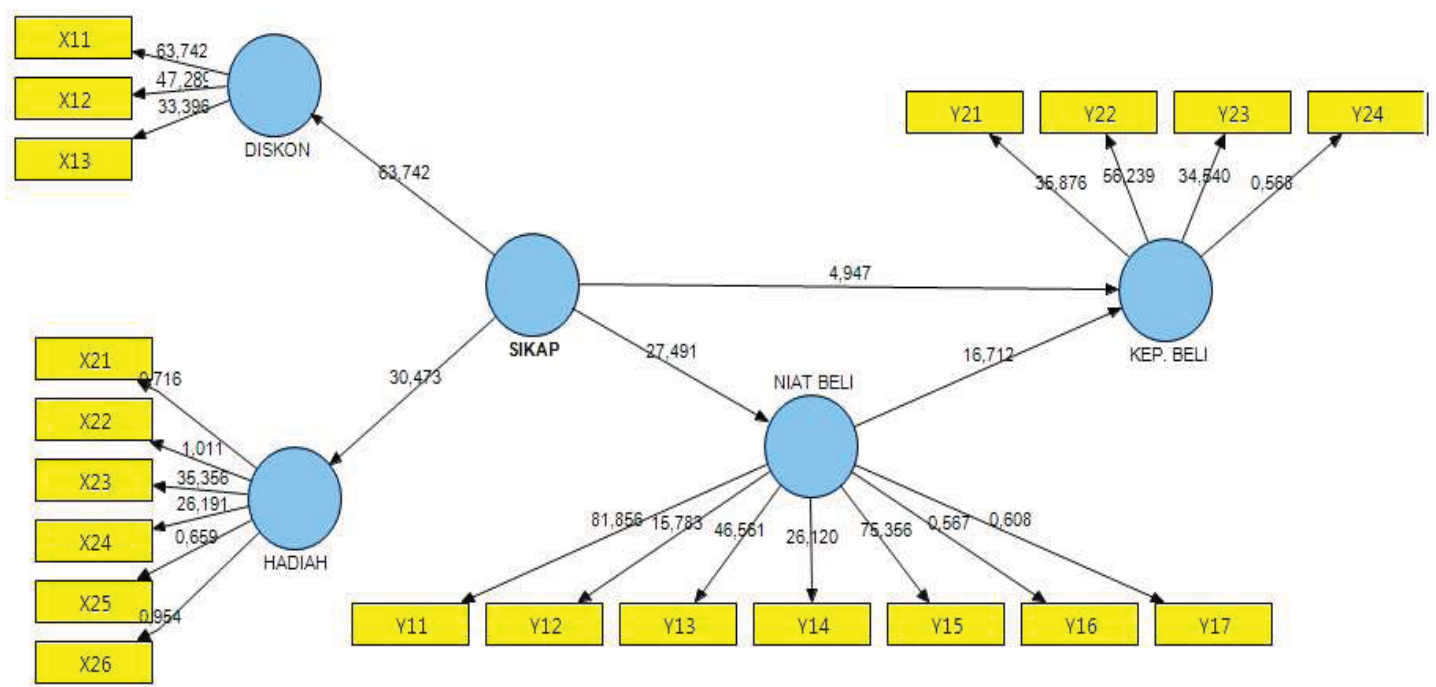

Gambar 6: Model diagram jalur dengan metode Boostraping

Berdasarkan tabel 13 dan gambar 4 di atas dapat disimpulkan bahwa seluruh hipotesis yang diajukan dalam penelitian ini diterima.

Dari hasil analisis deskriptif, diketahui bahwa konsumen lebih memiih hadiah daripada diskon, hal ini tidak lepas dari tipe toko yang dipilih yaitu toko ritel. Pelangan toko ritel sebagian besar merupakan pengguna terakhir dari produk (end user). Produk yang dibeli langsung dikonsumsi oleh mereka. Disamping itu jumlah pembelian mereka sesuai dengan kebutuhannya. Dengan demikian jumlah pembelian yang kecil besarnya diskon tidak terasa, sedangkan hadiah sendok dapat dirasakan langsung manfaatnya selain itu hadiah tersebut bersifat nyata dan berwujud.

Pengolahan data yang berkaitan dengan pengujian hipotesis di atas, sikap atas diskon dan hadiah berpengaruh efektifdalam mempengaruhi niat pembelian. konsumen memiliki sikap yang positif terhadap diskon dan hadiah, sikap yang positif tersebut mempengaruhi niat pembelian. Hal ini sesuai dengan hasil dari penelitian yang dilakukan oleh Alister et.al., (1990) mengemukakan bahwa adanya promosi penjualan berupa hadiah akan menarik 
perharian konsumen, sehingga konsumen akan menilai (menyikapi) dari hadiah tersebut terhadap produk yang dijual. Selain itu hadiah juga memberi dampak langsung terhadap niat pembelian. Artinya promosi berupa hadiah memiliki pengaruh terhadap niat pembelian.

Sementara Marcia et.al.,(2010) dalam penelitiannya tentang sikap konsumen terhadap promosi discount pada bumbu pasta. Hasil penelitiannya mengatakan bahwa sikap positif konsumen terhadap discount pada bumbu saus pasta memberikan keyakinan yang kuat dalam melakukan pembelian. Selain itu niat pembelian terjadi jika konsumen memiliki sikap yang positif terhadap discount pada bumbu saus pasta. Namun berbeda dengan hasil penelitian yang dilakukan oleh Raghubir (2008) yang menyatakan bahwa penawaran promosi dengan hadiah gratis (bukan produk) kurang efektif dan akan mengurangi daya tawar produk kepada konsumen sehingga akan mempengaruhi niat pembelian konsumen.

Niat pembelian memiliki pengaruh yang positif terhadap keputusan pembelian, hal ini sesuai dengan the theory of planned behaviour yang menyatakan bahwa niat mampu memprediksi terjadinya pembelian. Hasil penelitian ini mendukung penelitian yang dilakukan oleh James Elias et.al.,(2010) dalam penelitiannya menjelaskan bahwa niat pembelian konsumen terhadap keputusan pembelian diwarnai oleh tingkat pengetahuan konsumen mengenai produk dan kualitas produk. inti dari penelitiannya adalah mengenai konsumen yang memiliki cukup bekal informasi tentang atribut produk akan mendorong konsumen dalam berniat membeli dan pada akhirnya keputusan pembelian akan terjadi, jika niat yang dimiliki cukup besar.

Pengaruh langsung sikap terhadap keputusan pembelian melalui niat lebih efektif daripada pengaruh langsung tanpa memalui niat. Bentuk dari sikap berpengaruh langsung terhadap keputusan pembelian yaitu pembelian tidak terencana atau yang lebih dikenal dengan nama impulse buying. Impulse buying merupakan tindakan membeli yang dilakukan tanpa adanya permasalahan awal atau tanpa adanya niat sebelum memasuki toko (Mowen \& Minor, 2001). Impulse buying dapat terjadi jika pada saat memasuki toko atau melihat produk terdapat perasaan positif atau sikap positif terhadap produk tersebut.

Dengan kata lain impulse buying terjadi disebabkan oleh faktor emosi untuk melaklukan pembelian. Impulse buying akan sulit terjadi jika kondisi toko dan orang tidak mendukung adanya keinginan untuk membeli tanpa perencanaan terlebih dahulu dan impulse buying sulit diprediksi sebelumnya bahkan orang yang melakukannya tidak bisa memprediksinya. Sedangkan pengaruh sikap terhadap keputusan pembelian melaui niat akan mudah diprediksi karena adanya sikap terhadap suatu produk yang didorong oleh niat yang kuat akan mempermudah terjadinya pembelian. Artinya pembelian yang terjadi sudah terncana sebelumnya karena adanya suatu niat sebagai bahan evaluasi untuk melakukan pembelian.

\section{SIMPULAN}

Berdasarkan analisis data dan pembahasan hasil penelitian yang telah dikemukakan pada bab terdahulu, dapat ditarik kesimpulan sebagai berikut, yang pertama Konsumen lebih memilih program promosi berupa hadiah sendok, kedua adalah sikap atas diskon dan hadiah secara signifikan berpengaruh terhadap niat pembelian. Hal ini ditunjukkan oleh tingkat signifikansi pengaruh variabel sikap atas diskon dan hadiah terhadap niat pembelian. Artinya bahwa sikap konsumen terhadap diskon dan hadiah memiliki efektifitas dalam mempengaruhi niat beli, dengan kata lain bahwa Promosi penjualan dalam bentuk diskon dan hadiah memiliki efektifitas dalam mempengaruhi niat pembelian dan keputusan pembelian, ketiga yaitu niat beli memiliki pengaruh yang signifikan terhadap keputusan pembelian. Hal ini ditunjukkan oleh besarnya nilai t-statistik yang lebih besar daripada t tabel. Disamping itu kedua variabel tersebut memiliki arah hubungan yang positif, hal ini didasarkan oleh nilai koefisien korelasi, terakhir adalah sikap atas diskon dan hadiah berpengaruh secara signifikan terhadap keputusan pembelian. Dari hasil analisis data diketahui nilai t-statistik pengaruh antar variabel tersebut lebih besar daripada nilai t-tabel. Bentuk 
dari keputusan pembelian yang dipengaruhi oleh sikap tanpa adanya niat yaitu adanya pembelian tanpa terencana yang dikenal dengan impulse buying. Impulse buying merupakan pembelian terjadi tanpa adanya niat terlebih dahulu.

\section{DAFTAR PUSTAKA}

Alister, Scott B, D. Jobber. Environmentally responsible purchase behaviour: a test of a consumer model. European Journal of Marketing, Vol. 34

Drhuv G, R Krishnan, Julie B, \& Norm. (2001). The Effect of Store Name, Brand Name and Price Discounts on Consumers' Evaluations and Purchase Intentions. Department of Marketing. University of Miami.

Gail Ayala Taylor, Scott A. Neslin, (2004). The Current and Future Sales Impact of a Retail Frequency Reward Program. See Journal of Retailing,, 81 (4), 293-305

Gbadamosi Ayantunji. (2007). Proceedings of the Salford Postgraduate Annual Research Conference. SPARC

Gendro Wiyono. (2011). Merancang Penelitian Bisnis: Dengan alat analisis SPSS \& Smart PLS 2.0. Yogyakarta: UPP STIM YKPN

James Elias. Rizaimy S.M. Shaharudin W. Mansour. (2010). Food Quality Atribute Among Malaysia's Fast food Customer. Canadian Research \& Development Center of Sciences and Cultures.

Joel Lexchin and Barbara Mintzes.(2002). Directto-Consumer Advertising of Prescription Drugs:The Evidence Says No. 194 Journal of Public Policy \& Marketing Vol. 21 (2) Fall, 194-201

Lemchi. P, Murphy. J \& Ben M. Enis. (2008). Effect of Sales Promotion on the Volume of Agro Product (ROYCO). Journal of Marketing ABI/INFORM Global pg. 42

Manfred Kraft. Murali K Matrala. (2006). Retailing In The 21 St Century. Current and future Trends
Marcia de barcellos. Jens O. Kugler. Klaus G. Grnnet. (2010). European consumers'acceptance of beef processing technologies. A focus group study flavoring pasta sauces. Journal of Food \& Seasoning. Volume 11. Issue 4

Mowen, Jihn C. Michael Minor. (2001). Consumer Behavior. Harcourt College Publisher

Nira Liberman, Loraine Chen Idson, Promotion and Prevention Choise Between Stability adn Change. Journal of Personality and Social Psychology. Vol.77. no. 6. 1135-1145

Philip Kotler \& Kevin L. Keller. (2009). Manajemen Pemasaran. Edisi 12 Jilid 1. Jakarta. Indeks

Priya Raghubir (2004). Free Gift with Purchase: Promoting or Discounting the Brand? Journal of Consumer Psychology., 14(1\&2), 181-185

Priya Raghubir (2008). Promoting Promotions: Why Does Increase The Visual Size Of The Free Gift Backfire. Revised for the Journal of Product and Brand Management:

Raman K, \& Prasad. A. N (2011). Integrated Marketing Communications in Retailing. Loughborough University, Leicestershire, UK.

Rockney G. Walters and Scott B. \& MacKenzie. (1998). A Structural Equations Analysis of the Impact of Price Promotions on Store Performance Author(s). Journal of Marketing Research, Vol. 25, No. 1, pp. 51-63 Published by: American Marketing Association

Saifuddin Azwar. (1995). Sikap Manusia: Teori dan Pengukurannya. Edisi ke 2. Yogyakarta: Pustaka Pelajar

Teresa Montaner, \& José-Miguel Pina.(2008). The Effect Of Promotion Type And Benefit Congruency On Brand Image. The Journal of Applied Business Research Volume 24, Number 3

Tsai Min. (2002). Purchasing and consumption behaviors, attitudes, opinions and expectations of Taiwanese urbanites toward 
cheese. Thesis, Desertation, and Student Research Papers (Food Science and Technology).

Vaishnani Haresh B., (2011). Effects of Sales Promotions on Consumer Preferences and Brand Equity Perception: with specific ref- erence to FMCG Products, thesis PhD, Saurashtra University.

Widayat (2011). Perilaku Berinvestasi: Perspektif Mixed Method. Malang: Aditya Media 